\title{
XK Gene Mutation
}

National Cancer Institute

\section{Source}

National Cancer Institute. XK Gene Mutation. NCI Thesaurus. Code C150708.

A change in the nucleotide sequence of the XK gene. 